\title{
UPACARA MEJRIMPEN PADA HARI RAYA GALUNGAN DI DESA PEDAWA KABUPATEN BULELENG
}

\author{
Dewa Nyoma Sucita \\ STKIP Agama Hindu Singaraja, \\ dewasucita58@gmail.com
}

\begin{abstract}
ABSTRAK
Tujuan yang ingin diperoleh dari penelitian ini adalah dapat mengungkap hal ikhwal pelaksanaan upacara Mejripen di desa Pedawa, yang bersifat cukup unik karena hanya dilaksanakan oleh umat Hindu yang berada di desa Pedawa. Untuk menuntaskan penelitian ini digunakan beberada metode ilmiah antara lain: dalam menentukan informan digunakan purposive snowball sampling; untuk mendapat data digunakan metode observasi, wawancara dan pencatatan dokumen. Dan data yang terkumpul diolah dengan metode analisis data kualitatif. Adapun hasil yang diperoleh sebagai berikut: 1). Upacara mejrimpen adalah upacara manusa yadnya menggunakan banten jrimpen sebagai upakara pokok yang mengandung berbagai makna antara lain: sebagai upacara pembersihan diri, upacara sambutan (Telu Bulanan), upacara ngotonin dan upacara syukuran. 2). Tatacara pelaksanaan upacara Mejrimpen ada dua bagian besar, yaitu pertama, tatacara Mejrimpen Sibakan yang meliputi a). Pemotongan babi untuk bahan pembuatan sate banten Jrimpen dilaksanakan pada Penampahan Galungan, b). Babi yang dipotong dipakai separuhnya untuk pembuatan bahan sate Jrimpen, c). Tidak membuat banten segehan pada pintu gerbang pekarangan dan tidak membuat banten Karna untuk di Sanggah Kemulan Sakti, d) Setelah sate yang dibuat dihiyasi dengan berbagai pariasi dari kulit babi, lemak, hati, cabe dan kunir selanjutnya beberapa sate tersebut dipajang setinggi tiang bendera di atas atap rumah. Kedua, tatacara upacara Mejrimpen Nampah Ukudan meliputi: a). Pemotongan babi untuk bahan pembuatan sate banten Jrimpen dilaksanakan pada hari raya Galungan, b). Babi yang dipotong sepenuhnya untuk pembuatan sate Jrimpen, c). Membuat banten segehan yang diaturkan di pintu gerbang rumah dan banten karna untuk di Sanggah Kemulan Sakti, d). Tidak ada penunjukkan sate di atas atap rumah seperti pelaksanaan Mejrimpen Sibakan, e). Setelah sate dibuat langsung sate-sate itu ditata sedemikian rupa dalam sebuah wakul menjadi jrimpen sate dan saat itu pula dibuat jrimpen jaja. Setelah semuanya selesai kedua jrimpen itu ditata secara berjejer di atas bale-bale tempan pelaksanaan upacara Mejrimpen. Sore harinya dilanjutkan pelaksanaaan upacara Mejrimpen dan diakhiri dengan nunas tirta wayang dari ki dalang apabila upacara Mejrimpen yang dilaksanakan tingkat mewayang. 3). Ada dua jenis banten yang digunakan, yaitu: 1). Jenis-jenis banten yang digunakan pada upacara Mejrimpen Sibakan dan 2). Jenis-jenis banten yang digunakanpada upacara Mejrimpen Nampah Ukudan; sedangkan pada upacara Mejrimpen Mewayang, baik Mejrimpen Sibakan maupun Mejrimpen Nampah Ukudan masing-masing tingkatan ditambah dengan banten wayang.
\end{abstract}

Kata kunci : upacara Mejrimpen

\section{ABSTRACT}

This study aimed to uncover the event of the Mejrimpen ceremony in the Pedawa Village, which is quite unique because it is only carried out by Hindus in Pedawa Village. To complete this study several scientific methods were used including: purposive snowball sampling to determine the subjects of the research; observation, interview and document recording to collect data. The results were processed using qualitative data analysis methods. The results obtained were as follows: 1). Mejrimpen ceremony is a ceremony that uses Jrimpen offering as a main offering which contains various meanings, such as self- 
Jurnal Widya Sastra Pendidikan Agama Hindu, Vol. 3, No. 22020

e-ISSN : 2656-7466, p-ISSN : 1907-9559

cleaning ceremony, welcoming ceremony (when the baby is 3 months old), ngotonin ceremony and thanksgiving ceremony. There are two major procedures for carrying out the Mejrimpen ceremony, namely first, the Mejrimpen Sibakan procedure which includes a). Slaughtering pigs for satay used in Jrimpen offering which is carried out in Penampahan Galungan, b). The cut pork is used in half for making Jrimpen satay ingredients, c) Not making segehan offerings in front of the house gate and not making Karna offering for Sanggah Kemulan Sakti. d) After the satay were filled with pork skin, fat, liver, chilli and turmeric, they were displayed as high as a flagpole on the roof of the house. Second, the procedures for Mejrimpen Nampah Ukudan ceremony include: a). Slaughtering pigs for Jrimpen offering is carried out on Galungan, b). Pigs are fully cut for making Jrimpen satay, c). Making segehan offerings which are arranged at the gate of the house and karna offering for the Sanggah Kemulan Sakti, d). There is no satay displayed on the roof of the house like the implementation of the Sibakan Mejrimpen, e). After the satay are made, they are arranged in such a way in a wakul as the jrimpen satay and at that time the jrimpen snack is also made. After everything is finished, the two jrimpen are arranged in a row above the balebale where the Mejrimpen ceremony is held. The ceremony is continued in the afternoon with Mejrimpen ceremony and ended with the gift of wayang holy water from the puppeteer when the Mejrimpen ceremony was held at the wayang level. 3). There are two types of offerings used, namely: 1). The types of offerings used at the Sibakan Mejrimpen ceremony and 2). The types of offerings used at the Mejrimpen Nampah Ukudan ceremony; while at the Mejrimpen Mewayang ceremony, both Mejrimpen Sibakan and Mejrimpen Nampah Ukudan were added with wayang offerings.

\section{PENDAHULUAN}

Kehidupan beragama Hindu di Bali tidak bisa dipisahkan dengan pelaksanaan upacara. Upacara dilaksanakan oleh umat Hindu di Bali secara bersinambungan tanpa putus-putusnya. Setiap hari sehabis masak di dapur para ibu dalam setiap keluarga akan melaksanakan upacara ngejot atau ngaturang banten saiban. Setelah itu dilanjutkan dengan mempersembahkan atau ngaturang canang. Setiap lima belas hari ngaturang upacara Purnama dan lima belas hari kemudian ngaturang upacara Tilem. Ditambah lagi dengan upacara-upacara hari-hari suci seperti pujawali di tempat suci keluarga (Sanggah/Merajan), tempat suci Tri Kahyangan (Pra Desa, Pura Puseh, Pura Dalem), pura Sad Kahyangan, Pura Dangkahyangan, pura Jagat, Galungan Kuningan, Nyepi dan lain-lain. Lebih-lebih kalau dikaitkan dengan lima jenis upacara/yadnya yang ada yang selalu dilaksanakan umat di antaranya: upacara Dewa Yadnya, upacara Rsi Yadnya, upacara Pitra Yadnya, upacara Bhuta Yadnya dan upacara Manusa Yadnya. Masing-masing upacara ini banyak jenis dan ragamnya. Inilah yang menyebabkan kehidupan beragama Hindu di Bali tidak bisa dipisahkan dengan upacara atau Yadnya.

Perlu diktekankan bahwa setiap upacara yang dilaksanakan oleh umat Hindu di Bali selalu disesuaikan dengan situasi, kondisi dan keadaan (desa, kala dan patra) di mana dan oleh siapa upacara itu dilaksanakan serta tingkatan upacara yang diambil, apakah tingkat kecil (nista), tingkat menengah (madya) atau tingkat besar (agung). Hal ini yang menyebabkan pelaksanaan jenis upacara yang sama berbeda-beda, antara orang satu dengan orang yang lain, antara desa yang satu dengan yang lain. Misalnya seseorang yang berada melaksanakan upacara ngotonin, karena mengambil tingkatan agung tentu upakara/banten yang digunakan dalam upacara itu sangat banyak dan biaya yang sangat besar; sebaliknya bagi orang yang miskin mengabil upacara ngotonin dengan tingkatan nista tentu banten atau upakara yang digunakan sangat sedikit, sehingga biaya yang dihabiskanpun sedikit pula. Demikian pula kalau kita hubungkan dengan desa, kala dan patra, di masing-masing desa memiliki adat, tata upacara dan jenis upacara yang berbedabeda, sehingga tampak bahwa umat Hindu melaksanakan upacara tidak memiliki pegangan dan pedoman. Semestinya hal ini harus disadarai bahwa secara kasat mata berbeda, namun secara makna dan tujuan pada dasarnya sama. 
Jurnal Widya Sastra Pendidikan Agama Hindu, Vol. 3, No. 22020

e-ISSN : 2656-7466, p-ISSN : 1907-9559

Terkait dengan berbagai ragam pelaksanaan upacara yang dilaksanakan oleh umat Hindu di Bali, di desa Pedawa, Kecamatan Banjar, Kabupaten Buleleng merupakan salah satu desa Baliage di Bali Utara, memiliki satu upacara unik yang dilaksanakan oleh masyarakat Pedawa, yang tidak kita dapatkan di desa lain, yakni upacara Mejrimpen. Pada umumnya di Bali, Jerimpen itu dikenal sebagai salah satu banten yang digunakan pada upacara-upacara tertentu saja. Namun di Pedawa, di samping dikenal Jrimpen sebagai salah satu banten/jenis upakara, juga dikenal pula sebagai salah satu upacara, yakni upacara Mejrimpen. Mengingat upacara ini bersifat khusus, hanya dilaksanakan oleh masyarakat Pedawa, tentu masyarakat di luar Pedawa atau masyarakat Bali pada umumnya tidak memahami upacara Mejrimpen ini. Inilah yang sangat menarik untuk diteliti, sehingga upacara Mejrimpen ini ditetapkan menjadi obyek penelitian. Dengan harapan nantinya dapat mengungkap berbagai hal ikhwal tentang upacara Mejrimpen ini antara lain a). Pengertian dan makna upacara Mejrimpen, b). Tatacara pelaksanaan upacara Mejrimpen, dan c). Jenis baten yang digunakan dalam upacara Mejrimpen.

\section{METODE PENELITIAN}

Penelitian kualitatif ini dilaksanakan di desa Pedawa, Kabupaten Buleleng karena fenomena obyek penelitiannya didapatkan di desa Baliage ini. Prosudur yang ditempuh untuk menyelesaikan penelitian ini menggunakan beberapa metode yang bersifat ilmiah. Dalam menentukan subyek/ informan digunakan purposive snowball sampling. Dengan teknik ini informan yang dipilih adalah orang-orang yang memahami dengan baik tentang obyek penelitian; yang diawali dengan pemilihan informan kunci, kemudian jumlah semakin banyak dan diakhiri apabila dipandang cukup. Dalam hal ini informannya orang-orang yang dipilih berasal dari tokoh agama/adat, tokoh masyarakat, tukang banten/sarati banten/capini, dan pemangku/jro balian.

Data yang diperlukan dalam penelitian ini berupa keterangan-keterangan tentang hal ikhwal upacara Mejrimpen dari para informan. Adapun teknik yang digunakan untuk mengumpulkan data adalah observasi, wawancara dan pencatatan dokumen. Jenis observasi yang digunakan adalah observasi partisipasi pasif (passive participation) tidak berstruktur sehingga peneliti hanya sebagai pengamat dan tidak menyiapkan secara sistematis apa yang akan diamati karena belum diketahui secara pasti apa yang diamati. Teknik wawancara yang digunakan adalah tak berstruktur, sehingga peneliti dapat mengajukan berbagai pertanyaan lanjutan yang lebih terarah pada suatu tujuan. Pertanyaan lanjutan itu bertujuan untuk mempertajam data yang diperoleh sehingga menjadi data yang kredibel. Data yang diperoleh dari wawancara dan observasi akan lebih kredibel atau dapat dipercaya apabila didukung oleh dokumen berupa catatan, peraturan, dan lainnya yang dianggap sebagai dokumen pendukung data penelitian.

Data yang diperoleh harus dapat memberikan jawaban terhadap masalah yang dirumuskan oleh karena itu harus dianalisis. Dalam menganalisis data digunakan analisis data kualitatif model Miler dan Heberman. Kedua ahli ini mengatakan bahwa aktivitas dalam analisis data kualitatif dilakukan secara interaktif dan berlangsung secara terus menerus sampai tuntas, sehingga datanya jenuh. Ukuran kejenuhan data ditandai dengan tidak diperolehnya lagi data atau informasi baru. Pada dasarnya analisis data kualitatif ini meliputi tiga tahapan, yaitu reduksi data (data reduction), penyajian data (data display) dan penarikan kesimpulan / verifikasi (conclusion drawing/verification)

\section{HASIL DAN PEMBAHASAN}

\section{Pengertian dan Makna Upacara Mejrimpen}

Dalam Kamus Bali-Indonesia (1990: 292) disebutkan Jrimpen adalah sajen dibuat dari sebuah keranjang yang panjang diletakkan tegak diisi beberapa jenis kue dialasi dengan sebuah bakul yang berisi beras, sirih, benang putih dan uang dan di atas keranjang diisi 
Jurnal Widya Sastra Pendidikan Agama Hindu, Vol. 3, No. 22020

e-ISSN : 2656-7466, p-ISSN : 1907-9559

sampian khusus untuk jrimpen. Menurut Ida Pedanda Gd. Pemaron, (dalam Sudarsana, 2001:31) bahwa kata Jerimpen berasal dari dua suku kata yaitu " jeri" dan "empen", "jeri" berasal dari suku kata "jari" dan "empen" berasal dari "empu". Jari menjadi asta, (Asta Aiswarya) yang diartikan delapan penjuru dunia, sedangkan empu berarti Sang Putus (Maha Suci), diilustrasikan sebagai Sang Hyang Widhi, karena Sang Hyang Widhi lah yang mengatur dan memutuskan segala yang ada di alam semesta ini. Dengan demikian banten jerimpen merupakan simbol permohonan kehadapan Sang Hyang Widhi beserta manifestasiNya (Asta Aiswarya) agar beliau memberikan keputusan berupa anugrah baik secara lahiriah maupun bathiniah. Dalam Lontar Yadnya Prakerti disebutkan banten memiliki tiga arti sebagai simbul ritual yang sakral yaitu "Sahananing Bebanten Pinaka Raganta tuwi, Pinaka Warna Rupaning Ida Battara, Pinaka Anda Bhuvana artinya lambang dirimu atau lambang diri kita, lambang kemahakuasaan Tuhan dan lambang alam semesta (Bhuavana Agung). Banten sesungguhnya berasal dari kata "Bangten" dan terdiri dari dua suku kata yaitu "Bang" dan "enten" (bahasa Bali). Suku kata Bang bisa diartikan Brahma, dan Brahma menjadi Brahman (Sang Hyang Widhi). Sedangkan enten bisa diartikan "ingat" atau dibuat sadar (Sudarsana,2001:13). Jadi kata banten mengandung pengertian , bahwa umat Hindu, membuat banten untuk mendidik dirinya supaya selalu igat dengan keberadaan Sang Hyang Widhi karena beliau adalah pencipta segala isi dunia ini.

Di desa Pedawa jrimpen tidak saja dikenal sebagai salah satu jenis upakara/banten, melainkan juga dikenal sebagai salah satu upacara yang mana upacara ini wajib menggunakan banten jrimpen. Oleh karena, ia merupakan suatu kegiatan atau aktivitas, maka kata "jrimpen' ditambah awalan "me', maka menjadi mejrimpen. Jadi yang dimaksud sesungguhnya dengan istilah upacara mejrimpen adalah upacara atau ritual yang menggunakan banten jrimpen sebagai upakara pokok. Artinya, setiap orang yang melaksanakan upacara mejrimpen di desa Pedawa wajib membuat atau mengaturkan banten jrimpen. Upacara ini ditujukan pada anak-anak (manusia) yang dilaksanakan tepat pada hari raya Galungan, yang pelaksanaannya terhadap seseorang dapat dilakukan lebih dari satu kali, bahkan ada yang melaksanakan sampai tujuh kali bahkan yang unik lagi ada yang melaksanakan terhadap seseorang yang telah meningggal. Oleh karena itu, upacara mejrimpen ini dapat digolongkan bagian dari upacara Manusa Yadnya. Pada hakekatnya upacara mejrimpen ini adalah upacara pembersihan terhadap seseorang baik secara lahir maupun bathin. Mengingat tujuannya adalah pembersihan diri, maka sangat tepat dilaksanakan pada hari raya Galungan yang mengandung pengertian yang sama seperti yang disebutkan dalam Lontar Sundarigama, yaitu Hari Rabu Kliwon Wuku Dungulan disebut Hari Raya Galungan disebutkan maknanya adalah : Patitis adnyana sandi galang apadang, maryakna sarwa byaparaning idep, artinya melaksanakan pemusatan pikiran menuju pada kesucian diri agar bersih dan suci serta menghilangkan semua pengaruh pikiran yang negatif yang membawa pikiran kacau dan kotor (Tim,2006:62). Perlu ditegaskan bahwa jenis upacara Mejrimpen di desa Pedawa dibedakan menjadi empat, yaitu: upacara Mejrimpen Sibakan, upacara Mejrimpen Sibakan Mewayang, uapacara Mejrimpen Nampah Ukudan dan uapacara Mejrimpen Nampah Ukudan Mewayang.

Bertitik tolak dari uraian di atas, maka upacara mejrimpen yang dilaksanakan oleh umat Hindu di desa Pedawa merupakan tradisi kuno yang perlu dipertahankan yang mengandung beberapa makna sebagai berikut.

\section{Upacara Mejrimpen sebagai Upacara Pembersihan}

Keyakinan masyarakat Pedawa orang yang lahir ke dunia penuh dengan keketoran (mala) dan masih dianggap cuntaka, sehingga anak tersebut tidak diperkenankan masuk ke tempat suci baik tempat suci keluarga maupun tempat suci umum. Untuk membersihan semua mala yang dibawa sejak lahir ini masyarakat Pedawa melaksanakan upacara Mejrimpen. Upacara Mejrimpen sebagai bentuk pembersihan atau penyucian baik lahir maupun bathin. Ini terbukti dalam upacara ini digunakan tirta pengerapuhan berfungsi melebur segala bentuk kotoran badan (stula sarira) dan tirta pengening-ngening untuk membersihan suksma sarira (jiwa). 
Jurnal Widya Sastra Pendidikan Agama Hindu, Vol. 3, No. 22020

e-ISSN : 2656-7466, p-ISSN : 1907-9559

\section{Upacara Mejrimpen sebagai Upacara Nyambutin}

Upacara Mejrimpen Hari raya Galungan yang diyakini sebagai hari kemenangan Dharma melawan Adharma, turunnya Dewa dan Dewi dari Kahyangan serta turunnya para roh leluhur. Terkait dengan hal inilah upacara Mejrimpen dilaksanakan sebagai bentuk penyambutan kepada para Dewa dan Dewi, para roh leluhur serta menyambut atma atau roh orang yang diupacarai, di mana yang bersangkutan mulai mengalami berbagai tantangan di dalam kehidupan kini dan mendatang. Masyarakat Hindu di luar desa Pedawa umumnya melaksanakan upacara nyambutin ini setelah bayi berumur 105 hari atau setelah bayi berumur tiga bulan (Team penyusun, 2006 : 218). Oleh karena itu, upacara nyambutin ini dikenal pula dengan sebutan upacara telu bulanan atau tigang sasihan. Dengan demikian upacara Mejrimpen ini dapat disetarakan dengan upacara tiga bulanan.

\section{Upacara Mejrimpen sebagai Upacara Ngotonin}

Umat Hindu di Bali pada umumnya memaknai upacara ngotonin merupakan rangkaian upacara manusa yadnya, yang dilaksanakan setelah si bayi berumur 210 hari atau enam bulan Bali, sebagai bentuk peringatan hari kelahiran yang umumnya disertai dengan pemotongan rambut (megundul), bertujuan untuk membersihkan ubun-ubun (siwa dwara). Setelah upacara ini dilaksanakan barulah si bayi diperkenankan menginjak tanah, diajak ke tempat-tempat suci baik tempat suci keluarga maupun Tri Kahyangan.(Team penyusun,2006 : 222).

Masyarakat Pedawa tidak umum melaksanakan baik upacara Telu Bulanin maupun upacara Ngotonin. Upacara yang tidak boleh ditiadakan justru upacara Mejrimpen ini. Umat memandang bahwa seorang anak bila sudah diupacarai upacara Mejrimpen berarti anak yang bersangkutan sudah diupacarai baik Telu Bulanin maupun Ngotonin. Namun belakangan ini, karena pengaruh umat Hindu pada umumnya, maka ada beberapa keluarga terutama yang ekonominya baik, pada anak-anak mereka diupacarai baik upacara Telu Bualanin, Ngotonin maupun upacara Mejrimpen ini. Yang perlu ditegaskan kembali bahwa uapacara Mejrimpen ini dilaksanakan setiap hari raya Galungan yang datangnya setiap enam bulan sekali setara dengan datangnya upacara Ngotonin bagi seseorang, maka bagi seorang anak yang diupacarai lebih dari satu kali bahkan ada yang melaksanakan tujuh kali upacara Mejrimpen ini, maka akan tampak pelaksanaannya seperti upacara ngotonin setiap enam bulan sekali.

\section{Upacara Mejrimpen sebagai Upacara Syukuran}

Di atas sudah disebutkan bahwa umat Hindu meyakini bahwa hari raya Galungan merupakan hari kemenangan Dharma melawan Adharma, hari turunnya para Dewa dan Dewi dari Kahyangan ke dunia serta turun para roh suci leluhur, maka menjadi kewajiban bagi umat tidak hanya menyambut Beliau tetapi wajib pula mengucapkan rasa syukur dan mengucapkan terima kasih kepada Hyang Widhi. Di desa Pedawa ucapan rasa syukur kepada Tuhan Yang Mahaesa, Ida Hyang Widhi Wasa diwujudkan dengan melaksanakan upacara Mejrimpen.

\section{Tatacara Pelaksanaan Upacara Mejrimpen di Desa Pedawa}

Upacara Mejrimpen ini dilaksanakan tepat pada hari raya Galungan, pada sore hari dan berakhir biasanya sampai malam. Ini berarti, pelaksanaan upacara Mejrimpen ini dilaksanakan setelah rangkaian upacara Galungan dilaksanakan. Apabila dihubungan dengan jenis upacara yang ada, umat di Pedawa melaksanakan Dewa Yadnya, yakni Galungan terlebih dahulu setelah itu baru dilanjutkan dengan pelaksanaan upacara Manusa yadnya, yakni upacara Mejrimpen.

Tempat pelaksanaan upacara Mejrimpen, bukan di tempat suci keluarga melainkan di dalam rumah atau balai tempat tidur yang diatur sedemikian rupa. Tempat pelaksanaan upacara sudah menandakan bahwa upacara Mejrimpen ini tergolong ke dalam upacara 
Jurnal Widya Sastra Pendidikan Agama Hindu, Vol. 3, No. 22020

e-ISSN : 2656-7466, p-ISSN : 1907-9559

manusa yadnya, sehingga semua prosesi pelaksanaannya di balai (madya mandala) dan bukan di utama mandala (sanggah/merajan). Umumnya umat Hindu di Bali setiap melaksanakan upacara yang tergolong manusa dan Pitra yadnya selalu dilaksanakan di Madya Mandala.

Pada umumnya yang menjadi pemimpin upacara dalam setiap ritual umat Hindu di Bali di antara Pendeta/Pedanda, Pemangku, Jro Balian, tapakan atau orang-orang yang telah melaksanakan upacara Dwijati. Namun dalam memimpin upacara Mejrimpen, pemimpin upacara bersifat unik dan tidak melibatkan pemimpin dari luar keluarga. Pada umumnya yang memimpin upacara Mejrimpen ini adalah salah seorang keluarga yang dituakan dari orang yang diupacarai, seperti ayah atau ibunya, kakek atau neneknya, paman atau bibiknya yang diikuti oleh seseorang atau sekelompok juru kidung. Oleh karena, selama pelaksanaaan upacara Mejrimpen berlangsung disertai dengan mendendangkan kekidungan yang bersifat khusus, yakni kidung warga sari Jrimpen. Berikut akan disampaikan beberapa petik kidung yang menyertai upacara Mejrimpen sebagai berikut.

Sang kangkung lungania sendu, Janggawari kampuhe masabuk, Dewangga halus, nagasoca lan kekeris,

Sumpang tunjung tutur,

Ningarukia sang pepelik, tangisiah ceti, Prapti nira mangiring hiyuning dharma, Warga sekar, pepek pancoran suci.

Sampunan iratu sendu, Sinampurayang, parekane lintang dusun, Lengis murub wong jero puri, Maka kutaning nyineb kori, Reregang lulang sena, apang ica idewa turun, Dong medal ke jaba Bali.

Memedek di pura agung, Mingkalihang lalang wadon, Mesekar kedapan geninjring,

Miwah anggrek sasih, munggwing gelung, Kadi bintang duhur gunung, Tuhu rupania ngererawit, sekadi bintang

siange,

tuhu rupania dewi ratih, sekadi rarasnia anak-anakku

solahnia

ngeraras alon, wus nembah

sami matur 
Jurnal Widya Sastra Pendidikan Agama Hindu, Vol. 3, No. 22020

e-ISSN : 2656-7466, p-ISSN : 1907-9559

Di atas sudah disebutkan bahwa upacara Mejrimpen ini dibedakan menjadi empat yaitu Mejrimpen Sibakan, Mejrimpen Sibakan Mewayang, Mejrimpen Nampah Ukudan dan Mejrimpen Nampah Ukudan Mewayang. Tatacara pelaksanaan masing-masing upacara ini berbeda-beda. Namun secara garis besarnya dapat dipilah menjadi dua bagian besar, yaitu tatacara pelaksanaan upacara Mejrimpen Sibakan dan tatacara pelaksanaan upacara Mejrimpen Nampah Ukudan. Sebab, tatacara upacara Mejrimpen Sibakan Mewayang pada dasarnya sama dengan upacara Mejrimpen Sibakan hanya saja pada upacara Mejrimpen Sibakan Mewayang setelah pementasan wayang dilanjutkan dengan nunas tirta wayang yang dilakukan oleh ki dalang. Demikian pula dengan pelaksanaan upacara Mejrimpen Nampah Ukudan Mewayang, setelah mengkuti rangkaian upacara Mejrimpen Nampah Ukudan Mewayang diakhiri dengan nunas tirta wayang.

Tatacara pelaksanaan upacara Mejrimpen ini sesungguhnya secara prinsip dibedakan menjadi dua bagian besar, yaitu tatacara Mejrimpen Sibakan dan tatacara Mejrimpen Nampah Ukudan. Adapun tatacara upacara Mejrimpen Sibakan sebagai berikut. 1). Pemotongan babi untuk bahan pembuatan sate banten Jrimpen dilaksanakan pada hari Penampahan Galungan, 2). Babi yang dipotong dipakai separuhnya untuk pembuatan bahan sate Jrimpen, 3). Tidak membuat banten segehan pada pintu gerbang pekarangan (angkul-angkul) dan banten Karna untuk banten di Sanggah Kemulan Sakti, 4) Setelah sate yang dibuat dihiyasi dengan berbagai pariasi dari kulit babi, lemak, hati, cabe dan kunir selanjutnya beberapa sate tersebut dipajang setinggi tiang bendera di atas atap rumah. Ini mengandung makna: a). Sebagai simbolis pengibaran panji-panji kemenangan leluhur dalam pergulatan dharma melawan adharma, b). Sebagai permakluman dan rasa syukur kepada Hyang Widhi atas terciptanya dunia dengan segala isinya, c). Sebagai permakluman kepada masyarakat bahwa akan ada pelaksanaan upacara Mejrimpen, d). Sebagai lambang keluhuran dan kesucian, dan e). Sebagai lambang bahwa upacara Mejrimpen sebagai upacara yang bernilai tinggi bagi masyarakat Pedawa 5). Besoknya, yakni pada hari raya Galungan sate-sate itu ditata dalam sebuah wakul menjadi banten Jrimpen sate dan saat itu pula dibuat banten jrimpen jajan. Apabila kedua jenis banten ini selesai baru ditaruh secara berjejer di atas bale-bale tempat upacara Mejrimpen itu dilaksanakan. Pada sore harinya dilanjutkan dengan pelaksanaan upacara Mejrimpen oleh orang yang dituakan dengan mendendangkan kekidungan wargasari Jrimpen oleh tukang kidung. Apabila upacara ini dilaksanakan dalam tingkat Mewayang, maka akan diakhiri dengan nunas tirta wayang oleh ki dalang. Adapun tatacara upacara Mejrimpen Nampah Ukudan sebagai berikut. 1). pemotongan babi untuk bahan pembuatan sate banten Jrimpen dilaksanakan pada hari raya Galungan, 2). Babi yang dipotong sepenuhnya untuk pembuatan sate Jrimpen, 3). Membuat banten segehan yang diaturkan di pintu gerbang rumah dan banten karna untuk di Sanggah Kemulan Sakti, 4). Tidak ada penunjukkan sate di atas atap rumah seperti pelaksanaan Mejrimpen Sibakan, 5). Setelah sate dibuat langsung sate- sate itu ditata sedemikian rupa dalam sebuah wakul menjadi jrimpen sate dan bersamaan saat itu pula dibuat jrimpen jaja. Setelah semuanya selesai kedua jrimpen itu ditata secara berjejer di atas bale- bale tempan pelaksanaan upacara Mejrimpen. Sore harinya dilanjutkan pelaksanaaan upacara Mejrimpen dan diakhiri dengan nunas tirta wayang dari ki dalang apabila upacara Mejrimpen yang dilaksanakan tingkat mewayang.

\section{Jenis Baten yang Digunakan dalam Upacara Mejrimpen di Desa Pedawa}

Salah satu ciri dalam setiap upacara yang dilaksanakan dalam agama Hindu terutama umat Hindu di Bali adalah penggunaan berbagai sarana yang disebut upakara dalam bentuk banten. Demikian pula dalam upacara Mejrimpen ini digunakan berbagai jenis banten. Banten yang digunakan tersebut berbeda-beda sesuai dengan jenis Mejrimpen yang dilaksanakan. Adapun banten yang digunakan sebagai berikut.

\section{1). Banten yang Digunakan pada Upacara Mejrimpen Sibakan}


Jurnal Widya Sastra Pendidikan Agama Hindu, Vol. 3, No. 22020

e-ISSN : 2656-7466, p-ISSN : 1907-9559

Ada beberapa jenis banten yang digunakan pada upacara Mejrimpen Sibakan antara lain: Jrimpen jajan, Jrimpen sate, pajegan, punjung, nasi petayan, wakul, banten dulang, bakulan tetanjan jaja, tetanjan nasi, sagi, saji, dapetan pengiring dan sesalinan (kain)

2). Banten yang Digunakan pada Upacara Mejrimpen Sibakan Mewayang

Jenis banten yang digunakan pada upacara Mejrimpen Sibakan Mewayang adalah semua banten yang digunakan pada upacara Mejrimpen Sibakan di atas ditambah dengan beberapa jenis banten wayang antara lain: canang daksina, canang sari, burat wangi, peras, suci, canang raka, banten penyeked, ketipat gong, caru atuunan disertai tirta penglukatan.

3). Banten yang Digunakan pada Upacara Mejrimpen Nampah Ukudan

Ada berbagai jenis banten yang digunakan pada upacara Mejrimpen Nampah Ukudan yaitu jenis banten yang digunakan tiada lain sama dengan upacara Mejrimpen Sibakan antara lain : Jrimpen jajan, Jrimpen sate, pajegan, punjung, nasi petayan, wakul, banten dulang, bakulan tetanjan jaja, tetanjan nasi, sagi, saji, dapetan pengiring dan sesalinan (kain) ditambah dengan beberapa jenis banten yang lain, di antaranya banten pengulapan, pengambean, peras, penyeneng katututan nagasari, pesuguhan lawar dan banten karna.

4). Banten yang Digunakan pada Upacara Mejrimpen Nampah Ukudan Mewayang

Jenis banten yang digunakan pada upacara Mejrimpen Nampah Ukudan Mewayang pada dasarnya sama dengan banten yang digunakan pada upacara Mejrimpen Nampah Ukudan ditambah dengan banten wayang antara lain : canang daksina, canang sari, burat wangi, peras, suci, canang raka, banten penyeked, ketipat gong, caru atuunan disertai tirta penglukatan.

\section{KESIMPULAN} berikut.

Bertitik tolak dari uraian di atas, di bawah ini akan disampaikan simpulan sebagai

1. Pada dasarnya upacara mejrimpen yang dilaksanakan oleh masyarakat Pedawa dapat digolongkan sebagai upacara manusa yadnya menggunakan banten jrimpen sebagai upakara pokok yang mengandung berbagai makna antara lain: sebagai upacara pembersihan diri, upacara sambutan (Telu Bulanan), upacara ngotonin dan upacara syukuran bagi anak yang lahir ke dunia ini dengan harapan agar kelak anak yang lahir tersebut menjadi anak yang suputra, yang berguna bagi keluarga, masyarakat, bangsa dan agama.

2.Tatacara pelaksanaan upacara Mejrimpen dibedakan menjadi dua, yaitu: Pertama tatacara Mejrimpen Sibakan sebagai berikut. 1). Pemotongan babi untuk bahan pembuatan sate banten Jrimpen dilaksanakan pada hari Penampahan Galungan, 2). Babi yang dipotong dipakai separuhnya untuk pembuatan bahan sate Jrimpen, 3). Tidak membuat banten segehan pada pintu gerbang pekarangan (angkul-angkul) dan banten Karna untuk banten di Sanggah Kemulan Sakti, 4) Setelah sate yang dibuat dihiyasi dengan berbagai pariasi dari kulit babi, lemak, hati, cabe dan kunir selanjutnya beberapa sate tersebut dipajang setinggi tiang bendera di atas atap rumah. 5). Besoknya, yakni pada hari raya Galungan sate-sate itu ditata dalam sebuah wakul menjadi banten Jrimpen sate dan saat itu pula dibuat banten jrimpen jajan. Apabila kedua jenis banten ini selesai baru ditaruh secara berjejer di atas bale-bale tempat upacara Mejrimpen itu dilaksanakan. Pada sore harinya dilanjutkan dengan pelaksanaan upacara Mejrimpen oleh orang yang dituakan dengan mendendangkan kekidungan wargasari Jrimpen oleh tukang kidung. Apabila upacara ini dilaksanakan dalam tingkat Mewayang, maka akan diakhiri dengan nunas tirta wayang oleh ki dalang. Kedua tatacara upacara Mejrimpen Nampah Ukudan sebagai berikut. 1). pemotongan babi untuk bahan pembuatan sate banten Jrimpen dilaksanakan pada hari raya Galungan, 2). Babi yang dipotong sepenuhnya untuk pembuatan sate Jrimpen, 3). 
Jurnal Widya Sastra Pendidikan Agama Hindu, Vol. 3, No. 22020

e-ISSN : 2656-7466, p-ISSN : 1907-9559

Membuat banten segehan yang diaturkan di pintu gerbang rumah dan banten karna untuk di Sanggah Kemulan Sakti, 4). Tidak ada penunjukkan sate di atas atap rumah seperti pelaksanaan Mejrimpen Sibakan, 5). Setelah sate dibuat langsung sate-sate itu ditata sedemikian rupa dalam sebuah wakul menjadi jrimpen sate dan bersamaan saat itu pula dibuat jrimpen jaja. Setelah semuanya selesai kedua jrimpen itu ditata secara berjejer di atas bale- bale tempan pelaksanaan upacara Mejrimpen. Sore harinya dilanjutkan pelaksanaaan upacara Mejrimpen dan diakhiri dengan nunas tirta wayang dari ki dalang apabila upacara Mejrimpen yang dilaksanakan tingkat mewayang

3. Jenis banten yang digunakan dalam upacara Mejrimpen di desa Pedawa pada dasarnya dapat dipilah menjadi dua, yaitu: 1). Jenis-jenis banten yang digunakan pada upacara Mejrimpen Sibakan dan 2). Jenis-jenis banten yang digunakanpada upacara Mejrimpen Nampah Ukudan; sedangkan pada upacara Mejrimpen Mewayang , masing-masing tingkatan ditambah dengan banten wayang, yaitu upacara Mejrimpen Sibakan Mewayang, jenis banten Sibakan ditambah dengan banten wayang; demikian pula jenis banten Mejrimpen Ukudan Mewayang jenis banten yang digunakan jenis banten Ukudan ditambah dengan banten wayang.

\section{DAFTAR PUSTAKA}

Anandakusuma, Sri Reshi. 1959. Dharma Sastra. Denpasar: Pondok Ananda. 1983. Aum Kitab Suci Kusumadewa. Kelungkung: Satya Hindu Dharma. 1986. Aum Upacara Manusa Yadnya. Denpasar: CV. Kayumas.

Ardana, Suparta. 2002. Sejarah Perkembangan Agama Hindu di Indonesia. Surabaya: Paramita.

Asli, Luh. 2011. Upacara Tutug kambuhan di Desa Busungbiu Kabupaten Buleleng. STKIP Agama Hindu Singaraja.

Jaya Wijayananda, Ida Pandita Mpu. 2004. Makna Filosofis Upacara dan Upakara. Surabaya: Paramita.

Koentjaraningrat. 1972. Beberapa Pokok Antropologi Sosial. Jakarta: Dian Rakyat.

--------. 1981. Kebudayaan Mentalitas dan Pembangunan. Jakarta: Gramedia. 1990. Pengantar Ilmu Antropologi. Jakarta: Rineka Cipta.

Mas Putra, Ny. I Gusti Agung. tt. Upacara Dewa Yadnya. Denpasar: Yayasan Dharma Sarathi.

Prasarana

1987. Upacara Manusa Yadnya. Jakarta: Proyek Peningkatan Sarana dan Kehidupan Beragama.

1988. Panca Yadnya. Jakarta: Yayasan Dharma Sarathi. -------. 1996/1997. Upakara Yadnya. Denpasar: Proyek Peningkatan Sarana dan
Prasarana

Kehidupan Beragama. 
Jurnal Widya Sastra Pendidikan Agama Hindu, Vol. 3, No. 22020

e-ISSN : 2656-7466, p-ISSN : 1907-9559

Moleong, Lexy J. 2001. Metodologi Penelitian Kualitatif. Bandung: PT. Remaja Rosdakarya. Nawawi, Hadari. 1993. Metode Penelitian Bidang Sosial. Yogyakarta: Universitas Gajah Mada. Oka Netra, Anak Agung Gede. 1997. Tuntunan Dasar Agama Hindu. Jakarta: Hanoman Sakti. Pals, Daniel L. 2001. Seven Theories of Religion. Yogyakarta: Qalam.

Poerwadarminta, WJS. 1986. Kamus Umum Bahasa Indonesia. Jakarta: Balai Pustaka.

Pudja, Gde. 1978. Sarasamuscaya. Proyek Pengadaan Kitab Suci Agama Hindu Departemen Agama

$\mathrm{RI}$.

------. 1989. Weda Parikrama. Yayasan Dharma Sarathi.

--------. 1992. Theologi Hindu. Jakarta: Yayasan Dharma Sarathi.

1984. Bhagawadgita. Jakarta: Maya Sari.

Rasmawati, Putu. 1996 "Banten Suci dalam Upacara Tiga Bulanan Anak di Desa Banjar Kecamatan banjar Kabupaten Buleleng. STKIP Agama Hindu Singaraja.

Sagnan Sant Keshwodas. 1999. Gayatri, Semedhi Maha Tinggi. Jakarta: Penebar Swadaya. Sharma Smritidhara. 1985 A Glossary of Indonesian Blant names. Denpasar: Udayana Univercity. Sri Arwati, Ni Made. 2005. Bentuk, Funsi, dan Makna Upakara Piodalan.

Subaga, I Made. 1968."Riwayat Pulau Bali Jaman Ke Jaman".

Sudarsana, I.B. Putu. Tt. Ajaran Agama Hindu Uparengga. Denpasar: Mandara Sastra

-------. 2001. Ajaran Agama Hindu (Filsafat Yadnya). Denpasar: Yayasan Dharma Acarya. Dharma 2001. Ajaran Agama Hindu Makna Upacara Bhuta Yadnya.Denpasar: Yayasan Acarya. Acarya.

Sudharta, Tjok. Rai dan Oka Punyatmaja. 2005. Upadeca. Surabaya: Paramita.

Sura, I Gede, dkk. 1997. Tatwa Jnana. Jakarta: Proyek Pen. Pendd. Agama Hindu di Perti. Suryabrata. 1995. Metodologi Penelitian. Jakarta: PT. Raja Grapndo Persada.

Titib, I Made. 1989. Ketuhanan dalam Weda. Denpasar: Dharma Jati. 1996. Veda Sabda Suci Pedoman Praktis Kehidupan. Surabaya: Paramita. 2003. Teologi \& Simbol-simbol dalam Agama Hindu. Surabaya: Paramita. 2003. Tri Sandhya Sembahyang dan Berdoa. Surabaya: Paramita. 2004. Puran. Surabaya: Paramita. 
Jurnal Widya Sastra Pendidikan Agama Hindu, Vol. 3, No. 22020

e-ISSN : 2656-7466, p-ISSN : 1907-9559

Triguna, Ida Bagus Gede Yudha, 2000. Teori Tentang Simbol. Denpasar: Widya Dharma. Wiana, I Ketut. tt."Suksmaning Banten". Insitut Hindu Dharma Negeri Denpasar.

--------. 1995. Yadnya dan Bhakti dari Sudut Pandang Hindu. Jakarta: Swadaya. 2006. Menyayangi Alam Wujud Bhakti pada Tuhan. Surabaya: Paramita.

2007. Tri Hita Karana Menurut Konsep Hindu. Surabaya: Paramita. Widana, I Gusti Ketut. 2007. Lima Cara Beryadnya. Denpasar: Pustaka Bali Post. Wijayananda, Mpu Jaya. 2004. Makna Filosofis Upacara dan Upakara. Surabaya: Paramit 